\title{
O TRABALHO DIDÁTICO NA OBRA DE CALKINS: A ALFABETIZAÇÃO SEGUNDO O MÉTODO INTUITIVO
}

Enilda Fernandes

\section{RESUMO}

O presente artigo analisa o manual Primeiras Lições de Coisas, de autoria do norteamericano Norman Alisson Calkins, na versão modificada em 1870, traduzida por Rui Barbosa de Oliveira em 1881, e publicada no Brasil em 1886. Buscou-se enfocar o método e os conteúdos de alfabetização nesse manual, como foram articulados e as funções que lhe foram atribuídas. Para subsidiar o estudo, tomou-se a categoria organização do trabalho didático, formulada por Alves (2005), sendo a análise baseada no referencial metodológico marxista, situada a investigação no âmbito histórico. Assim, no exame do método e conteúdo desse manual, considerou-se importante captar os pontos essenciais característicos de inovação na organização do trabalho didático, em fins do século XIX e início do século XX, durante a transição do Império para a República. No decurso da investigação, caracterizou-se o fim utilitário que o livro em análise conferiu à alfabetização.

Palavras-chaves: trabalho didático; alfabetização; métodos e conteúdos.

\section{THE DIDACTIC WORK IN CALKINS' WORK: THE LITERACY ACCORDING TO THE INTUITIVE METHOD}

\begin{abstract}
The present article analyses the manual Primary Object Lessons written by the North American Norman Alisson Calkins, in the modified version in 1870, which was translated by Rui Barbosa de Oliveira in 1881, and published in Brazil in 1886. It was tried to focus on how the method and the literacy contents appeared in this manual, how they were articulated, and the functions that were attributed to it. To subsidize the study, the category didactic work's organization created by Alves (2005) was used, settling the analyses on the Marxist methodologic referential, situating the investigation on the historical scope. This way, in the examination of the method and content of this manual, it was considered important to capture the essencial points that were mentioned as characteristic of innovation in the didactic work's organization in the end of the 19th century and beginning of the 20th century, during the transition from Empire to Republic. In the course of the investigation, it was characterized the utilitarian purpose that the book analysed granted to literacy.
\end{abstract}

Key words: didactic work; literacy; methods and contents. 


\section{INTRODUÇÃO}

Esse texto corresponde a uma parte da tese de doutoradoi, defendida em 2014, na Universidade Federal de Mato Grosso do Sul/UFMS, orientada pela professora Dra. Silvia Helena Andrade de Brito.

Desde 2007, o Grupo de Estudos e Pesquisas História e Educação no Brasil, HISTEBR - regional de Mato Grosso do Sul - vem desenvolvendo estudos sobre os instrumentos de trabalho didático por considerar que esta temática, no âmbito da "organização do trabalho didático ii ", guarda elementos fecundos para análise no que tange aos métodos, aos instrumentos de ensino e à relação educativa. Assim, em 2010 o grupo elaborou um projeto interinstitucional, O manual didático como instrumento de trabalho nas escolas secundária e normal (1835-1945), financiado pelo CNPq e finalizado em 2012.

A referida tese vinculou-se a esse último projeto, tomando para estudo os métodos e os conteúdos de alfabetização em manuais didáticos utilizados tanto para a formação de professores como para o ensino na escola primária nos séculos XIX e XX. Um deles, foi o manual Primeiras Lições de Coisas, de autoria do norte-americano Norman Alisson Calkins, na versão modificada em 1870, traduzida por Rui Barbosa de Oliveira em 1881 e, publicada no Brasil em 1886. Os outros dois foram as obras de Manuel Bergström Lourenço Filho, Cartilha do Povo e Testes ABC, publicados respectivamente em 1929 e 1933.

Basicamente, foram três aspectos abordados no estudo: contribuir com uma reflexão sobre a alfabetização, pois nos métodos e conteúdos se revela efetivamente o rumo dado ao trabalho didático no processo de ensinar a ler e escrever; indicar em que medida o alfabetizar corrobora com o tipo de necessidade histórica posta nos séculos XIX e XX, e como isso se deu concretamente; e, por fim, compreender as necessidades históricas impostas ao ato de alfabetizar no Brasil e os interesses aos quais estavam ligadas, como também em que conjunturas política e econômica se configuraram tais propostas de se ensinar a ler e a escrever.

Para fins de produção desse artigo, extraiu-se da tese o capítulo que analisa o manual Primeiras Lições de Coisas de Calkins. Ressalte-se que, em meados do século XIX, com as perspectivas de desenvolvimento e de modernização do Brasil pela industrialização, a ampliação da escola se impõe de modo mais evidente. Rui Barbosa atento às mudanças que ocorriam nas sociedades mais desenvolvidas em fins do século XIX entendeu ser primordial a inovação no ensino, e propôs uma reforma geral na educação escolar. Esse manual é defendido de forma irrestrita por Rui Barbosa como a obra mais avançada para cumprir com as necessidades de reforma do ensino primário. No campo da pedagogia, impunha-se a inovação com a instituição de um novo método e novos instrumentos de trabalho didático. No pensamento do jurista, o manual de Calkins, Primeiras Lições de Coisas, balizado pelo método intuitivo, correspondia às características de inovação da educação, devendo, portanto, ser o único instrumento de trabalho nas mãos dos professores para mediar o ensino primário.

No interior da organização do trabalho didático, o manual didático forjado na modernidade, emergiu de uma necessidade histórica no bojo da construção da sociedade capitalista, no século XVII, em um empreendimento de João Amós Coménio, que inspirado na manufatura, imprimiu-lhe a função de base no trabalho docente. Conforme afirma Alves (2001), esse instrumento na condição de mediador do trabalho do professor, naquele momento histórico, foi imprescindível à universalização da instrução pública. Entretanto, a escola na contemporaneidade manteve aquela organização preservando-o 
como ferramenta de proa no trabalho escolar, em todos os níveis e áreas de ensino. Coménio em sua proposta recomendava o uso exclusivo de dois gêneros de livros: "livros de texto para o aluno e livros-roteiro (informatorii) para os professores, para que aprendam a servir-se bem deles" (COMÉNIO, 1957, p. 460). Os tais livros têm duas versões: uma que contém todo o programa prescrito, com a função específica de orientar o professor, e outra, para as atividades escolares do aluno. Eis o manual didático.

Para o ensino da arte de ler e escrever, o manual didático é expresso nas cartilhas com gravuras. Segundo a epistemologia comeniana, para o ensino das línguas nas escolas primárias - ludus literarius -, o método deveria assentar-se nos sentidos. Assim, o ensino deveria iniciar-se a vista dos objetos, devendo os manuais apresentar as imagens das coisas, isto é, produzir desenhos ilustrando os substantivos, exprimindo os artefatos e ações cotidianas descritas pelas orações. Logo, о Janua Linguarum, um livro de latim, vertido para o alemão em 1633 e aperfeiçoado pelo próprio Coménio com a impressão de figuras, foi publicado em 1658 como Orbis Sensualium Pictus - o mundo ilustrado. Dentro de um quadro histórico em que surge necessidade de ensinar a ler e escrever, Coménio propõe os livros didáticos breves e metódicos, dividindo as fases de estudo, conforme a idade, em quatro níveis ${ }^{\mathrm{iii}}$.

Para subsidiar esse estudo, tomou-se a categoria organização do trabalho didático, formulada por Alves (2005), no modo de ensinar, instituído por Coménio. Sendo esta categoria o elemento norteador deste trabalho, o método para orientar a análise é pautado na Ciência da História, de Marx e Engels (1991, p. 23), em a Ideologia Alemã, como sendo a única ciência capaz de examinar a história sob dois aspectos: "a história da natureza e a história dos homens". Compartilhando a síntese de Souza (2012), entende-se que só a história, tal como a pensaram Marx e Engels, permite definir a ciência nos seus limites mais abrangentes, como também a apreensão de qualquer objeto em sua gênese, desenvolvimento e obsolescência. Ciência da História implica um método determinado conforme a referida autora, "Método de investigação e análise das formas tornadas concretas e humanizadas pelo trabalho do homem, sob condições contraditórias". (SOUZA, 2012, p. 2).

Em consonância com o pensamento desses pesquisadores, adotou-se por base o princípio de que o exame de um objeto deve considerar a historicidade de todas as obras humanas. Nas palavras de Netto (2011, p. 42) "Marx distingue claramente o que é da ordem da realidade, do objeto, do que é da ordem do pensamento [...]". Assim, se se toma um objeto isolado do movimento real de sua produção, fica-se impedido de qualquer estudo de relações entre suas bases de origem e, portanto, obscurecido o entendimento de sua forma concreta de existência.

Em sendo assim, ao se assentar a análise da obra de Calkins, produzida em fins do século XIX, no referencial teórico metodológico marxista, buscou-se, situar a investigação essencialmente no âmbito histórico, examinando-a como instrumento determinado e criado para cumprir necessidades específicas que se transforma quando novas necessidades surgem. Nesses termos, o exame de manuais didáticos para ser uma síntese concreta de sua produção precisa ser tomado em sua origem, isto é, na base do trabalho manufatureiro, pois foi a técnica que inspirou Coménio na instituição da escola moderna.

A temática que norteia o presente trabalho sugere que os métodos e conteúdos impressos em manuais didáticos, designados à condição específica de instrumentos de trabalho, vinculam-se às exigências da especialização instituída no mundo moderno. Logo, a proposta de ensino de alfabetização funda-se na base técnica do trabalho imanente à sociedade capitalista burguesa. Isto significa que esse instrumento estabelecido na forma 
manufatureira do trabalho reproduz na pedagogia os limites do trabalho na manufatura. Ele expressa, em última instância, a simplificação e objetivação do trabalho didático.

Tomando a obra Primeiras Lições de Coisas: manual de ensino elementar para uso de pais e professores, de Calkins, buscou-se enfocar em como aparece o método e os conteúdos da alfabetização, bem em como foram articulados e as funções que lhe foram atribuídas. Esse manual, característico do tipo de organização do trabalho didático naquele momento histórico, traz a discussão e os procedimentos sistematizados de aplicação do método intuitivo. Indicado para ser o único livro nas mãos do docente do ensino elementar, prescreve: o que, como, e quando ensinar no processo de leitura e de escrita, daí tomá-lo empiricamente para análise.

No exame do método e dos conteúdos desse manual, considerou-se importante captar os pontos essenciais que foram aludidos como característicos da inovação na organização do trabalho didático, nas Lições de Coisas, na transição do Império para a República, imbuídos da conformação da pedagogia nos moldes científicos, para delinear os ajustes necessários e cabíveis à organização do ensino primário. Entendem-se como imprescindíveis estudos que analisem a alfabetização como necessidade histórica, dentro de uma determinada organização do trabalho didático, que elege os manuais como instrumento fundamental de ensino e da aprendizagem. Ademais, na atualidade, o processo de ensinar a ler a escrever nos anos iniciais de escolarização têm esses livros como instrumentos destinados à orientação metodológica de ensino e às atividades práticas a serem desenvolvidas pelos alunos.

O manual didático, instrumento que ganhou o caráter de portador dos métodos e conteúdos e de mediador do trabalho docente, tem sido desde os anos de 1970 objeto de interesse entre os pesquisadores da educação, com publicações expressivas em número significativo no campo acadêmico e científico, e com temáticas diversas envolvendo a problemática da alfabetização. No rol das produções acadêmicas, buscou-se nesse trabalho, pelo viés metodológico adotado, trazer uma contribuição singular, estabelecendo a análise dos métodos e conteúdos de alfabetização, cunhados no manual Primeiras Lições de Coisas, e no movimento universal que lhe confere historicidade. Tratou-se, então, de evidenciar que no movimento de mudanças estruturais na sociedade, marcado por antagonismo e contradições, o método intuitivo e conteúdo nele impresso traduziam as necessidades específicas em fins do século XIX e início do século XX.

Assim, para delinear o presente artigo, elaborou-se o texto em três partes: inicialmente, para caracterizar a historicidade dessas produções humanas, direcionou-se à abordagem aos primórdios da linguagem oral e sua objetivação na linguagem escrita, bem como as bases do manual didático no âmbito das origens da escola moderna. Depois, a obra propriamente dita no decurso da investigação. Por último, realizou-se o exame do método e do conteúdo, no qual se caracterizou o fim utilitário que o livro em análise conferiu a esse conhecimento e, também, os limites históricos do método intuitivo no ensino da leitura.

\section{BASES HISTÓRICAS: da linguagem oral e escrita aos instrumentos didáticos.}

É imprescindível, primordialmente, recuperar dados determinantes à compreensão do caráter histórico das produções humanas. A passagem de Marx e Engels propicia elementos para exercitar o pensamento em direção a tal concepção. 


\begin{abstract}
A linguagem é tão antiga quanto a consciência - a linguagem é a consciência real, prática, que existe para os outros homens e, portanto, existe também para mim mesmo; e a linguagem nasce, como a consciência, da carência, da necessidade de intercâmbio com outros homens. Onde existe uma relação, ela existe para mim: o animal não se "relaciona" com nada, simplesmente não se relaciona. Para o animal sua relação com os outros não existe como relação. A consciência, portanto, é desde o início um produto social, e continuará sendo, enquanto existirem homens (MARX E ENGELS, 1991, p. 43).
\end{abstract}

Desde os primórdios da história, primeiros homens sentiram a necessidade de criar condições para viver, instituir novas necessidades e renovar a própria vida. São esses os três aspectos da atividade social que para Marx e Engels (1991) coexistem e são sintetizados na produção da vida que, incessantemente, cria novas formas condicionadas pelas necessidades e pela práxis social. E assim, no processo de intercâmbios sociais, aprimorando sua consciência e linguagem como emanação de suas ações na base material, os homens criam instrumentos para mediar tais relações, objetivar e simplificar suas atividades.

As linguagens oral e escrita traduzem a particularidade humana em sua busca por inventar e desenvolver meios precisos às suas relações sociais. Como explicitam Marx e Engels (1991), examinado os aspectos produzidos pelo homem em suas relações históricas, verifica-se que, conforme produz os seus meios de vida e os instrumentos para mediar as suas relações, a sua consciência se alarga. De início, é primitiva, puramente natural, misturada ao meio sensível, numa relação determinada pela natureza; é tão animal quanto a própria vida, todavia é diferente do animal em si.

Para Vygotsky (1991) os macacos apresentam rudimentos de "linguagem" relativamente bem desenvolvidos, principalmente em termos fonéticos, que até se assemelham à fala humana. Porém, Vygotsky aponta que Koehler (1921) ao estudar os chimpanzés, vê que as expressões fonéticas expressam nada mais que desejos, afetos, desprovidos de sinais que impliquem algo objetivo. Não há conclusão de que os animais tenham atingido em suas ações um pensamento planejado. Embora tenham usado instrumentos e outras formas de comportamento aprendido, não demonstraram indícios de intenção em seus desenhos, representação ou atribuição de significado objetivo aos seus produtos.

O homem, por sua vez, de forma variada, já intencionava objetivar a fala, criando instrumentos e métodos para expressar os seres do mundo, começando pelo desenho, até chegar à palavra escrita, como forma de representar a linguagem oral. Portanto, o pensamento e a linguagem são características primárias do homem. A lógica é a de que, sob o influxo das necessidades que assomaram nas sociedades, a linguagem escrita e a leitura, bem como os instrumentos para seu registro - papiro, pergaminho e o papel impresso - e para a aprendizagem das novas gerações - métodos de ensino e conteúdos produzidas ao longo da história, modificaram-se, conforme as transformações na forma concreta de produção da vida.

Nesse quadro, sucessivas alterações promoveram o desenvolvimento da leitura e da escrita e, nesse processo, a alfabetização ganha historicamente um caráter bem específico. Em outros termos, ela tem os seus limites e extensão dentro do movimento de uma sociedade que se configura por contradições. Portanto, ela está dentro de um processo histórico que se distingue por novas necessidades e que demanda superações.

$\mathrm{O}$ ensino da linguagem escrita e da leitura apresenta-se articulado às condições materiais de cada época, e sua apropriação, como instrumento cultural, técnico ou social, 
vincula-se às transformações materiais instituídas nas sociedades, impregnando, portanto, em sua história, um conjunto de elementos que permitem detectar a sua dimensão histórica. Eis que a linguagem oral e a escrita, como objetos de expressão e de interlocução, comportaram formas diferentes em tempos diferentes, fato que funda a sua natureza histórica. Ao lado da invenção da escrita, a leitura teve significado diferente, e ambas apreendidas enquanto necessidades na sociedade resultam, fundamentalmente, de um processo que as integra: a alfabetização, que se dinamiza em um movimento histórico.

É fato que, em qualquer sociedade, todas as produções humanas são apropriadas de modo singular, dada as condições objetivas e subjetivas, para atender aos interesses e necessidades de seu tempo. Assim, também a escrita evoluiu em suas características linguísticas e, a seu lado, os instrumentos para a sua inscrição, desde os recursos naturais com técnicas pouco desenvolvidas até as tecnologias mais avançadas. A alfabetização tornou-se uma aquisição de base. Com a indústria tipográfica, o livro impresso despontava com a possibilidade de estabelecer a escola de um novo modo.

Na sociedade moderna, um livro é produzido com uma forma bem determinada: ser instrumento de trabalho, pensado e elaborado especificamente para mediar todas as atividades escolares. Esse livro se configura no próprio modo de ser da escola, questão que é problematizada e discutida por Gilberto Luiz Alves (2001, 2005), que traz à tona, insistentemente, os aspectos que envolvem a organização do trabalho didático, indicando que, historicamente, três elementos distintos correspondem a sua sistematização:

a) [...] uma relação educativa que coloca, frente a frente, uma forma histórica de educador, de um lado, e uma forma histórica de educando (s), de outro; Realiza-se com a mediação de recursos didáticos, envolvendo os procedimentos técnico-pedagógicos do educador, as tecnologias educacionais pertinentes e os conteúdos programados para servir ao processo de transmissão do conhecimento, E implica um espaço físico com características peculiares, onde ocorre. (ALVES, 2005, p. 1011, os grifos são do autor).

Tal como se anunciou na Introdução, objetiva-se a partir do manual de Calkins focar a análise em um desses aspectos, mais precisamente os métodos e conteúdos, sem deixar de tocar na relação educativa, como também na disposição física do espaço escolar, pois eles são elementos interligados que, em sua articulação, produzem mudanças qualitativas no trabalho didático.

Notem-se que no processo de transição do feudalismo para o capitalismo a educação foi um dos projetos que corresponderam ao ideário da nova sociedade, por meio do movimento da Reforma Protestante contra a Igreja feudal, iniciado com Martinho Lutero (1483-1546) ${ }^{\mathrm{iv}}$. Porém, encontrar respostas adequadas, precisas e ajustadas a uma nova forma de organizar o processo escolar e a possibilidade de expansão escolar, coube a João Amós Coménio (1592-1670).

Em 1624, em decorrências de perseguições religiosas, Coménio refugiou-se em Líssa e viu-se diante da proposição de Lutero com seu apelo "Aos conselhos de Todas as Cidades da Alemanha para que criem e mantenham escolas cristãs" (LUTERO, 2011, V. 5, p. 302), constituindo o lema "ensinar tudo a todos" e defendendo a criação de uma escola universal. Na sua obra Didáctica Magna, publicada em 1657, definia as suas diretrizes para a pedagogia e indicava o método seguro para a obtenção de bons resultados para os alunos e professores.

Duas condições materiais foram historicamente fundamentais na construção de sua didática: o modo de produção de trabalho manufatureirov ${ }^{v}$ e a tecnologia da imprensa. De 
um lado, a manufatura em pleno processo de amadurecimento brandia luz ao seu empreendimento, pois seguindo a mesma lógica fundada no processo de produção da manufatura, que supera o trabalho artesanal pela objetivação do trabalho nos instrumentos da fábrica, como indica Souza (2010), também assim poderia simplificar e objetivar o trabalho do mestre no manual didático. E, de outro lado, com a tecnologia da imprensa poderia concretizar a sua proposta de organização universal e perfeita das escolas, pois a tipografia em caracteres móveis transformou radicalmente a produção de livros e sua forma material transformou também as suas condições de apropriação: o livro deixava de ser feito de forma artesanal, passando a ser fabricado em série, ganhando um novo sentido, como mercadoria e como instrumento de trabalho, com a possibilidade de incorporar no trabalho didático maior número de alunos, com um menor número de professores.

Foi sob essa base material - a época de transição para o domínio da produção capitalista - que foi produzido o manual didático, na condição de instrumento de trabalho, que se programou o método que viria universalizar o ensino, com menor custo e maior aproveitamento do tempo, bastando para isso dar ao manual um tratamento racionalizado, tal como se faz na manufatura, e estabelecer as bases para cumprir o seu lema, "ensinar tudo a todos". Mas cabe frisar que a frase não expressava ensinar os conhecimentos que conduzissem a reflexão, pois que, dado o pragmatismo do pensamento burguês, convinha dar a todos os "fundamentos", de acordo com as necessidades devotadas ao fazer.

A utilidade e a prática eram elementos característicos da nova sociedade, e a todos deveriam dar um conhecimento exato e profundo, mas precisamente funcional, útil, com instrução para se fazer as coisas, cujo fim lhe foi posto no mundo e que se lhe ordenam que façam. Nesses termos, a organização didática deveria constituir um programa com os conteúdos básicos: ler, escrever, contar e medir, além de conteúdos de ordem mais geral, com métodos objetivos e práticos, metas bem definidas e um único instrumento, conduzindo-os em conjunto. Coménio (1957, p. 430) assim dizia:

A cada classe sejam destinados livros de textos próprios, que contenham todo o programa prescrito [...] para que, durante o espaço de tempo em que os jovens são conduzidos pelo caminho destes estudos, não tenham a necessidade de nenhum outro livro, e com ajuda desses livros possam ser conduzidos infalivelmente às metas fixadas [...].

Assim, os conteúdos eram divididos e sistematicamente organizados, sendo fixado para cada classe um livro com o programa distinto. Tal como o tipógrafo serve-se do compenedor para alinhar os caracteres e as palavras em linhas e as linhas em colunas, o professor também precisa de normas que o orientassem em tudo que haveria de fazer. Eis a especialização do instrumento de trabalho que alinha o trabalhador naqueles limites. Esse livro que seria o instrumento de base para compor a didática em seu conjunto é um livro com características bem peculiares, em sua forma e conteúdo, em duas versões, sendo um com orientações para o mestre e o outro para a atividade do aluno. Eis as palavras de Coménio (1957, p. 460):

[...] aos educadores da juventude, é necessário dar normas, em conformidade com as quais executem as suas obras, isto é, devem escrever-se para uso deles Livros-roteiros que os aconselhem quanto ao que hão-de fazer, em qualquer lugar e de que modo, para que não se caia em erro. Os livros didácticos serão, portanto, de dois gêneros: verdadeiros livros de textos para os alunos, e livros-roteiros (informatorii) para os 
professores, para que aprendam a servir-se bem deles. (COMÉNIO, 1957, p. 460, os grifos são do autor).

Como se vê, prescreve-se, nessa base, todo o programa escolar, de modo que mesmo aquelas pessoas que não fossem tão hábeis para ensinar, poderiam fazê-lo a contento, pois a elas não cabia pensar o que ensinar, mas apenas reproduzir o conteúdo, a partir do instrumento já preparado. Em sua obra Didáctica Magna, logo após a introdução, Coménio (1957, p. 44) afirma que se deve "investigar e descobrir um método no qual os professores ensinem menos e os estudantes aprendam mais; [...]". O tipo de educador e de relação educativa, até então realizado, não comportava a expansão da educação. Assim, era preciso dar ao trabalho didático uma forma simples e objetiva, para que qualquer homem mediano pudesse ensinar, e cujo fundamento seria ensinar e aprender rapidamente, facilmente, vantajosa e solidamente. Desse modo, o manual didático comportaria tal método, pois nele se poderia "consubstanciar uma síntese de conhecimentos humanos sob uma forma mais adequada ao desenvolvimento e à assimilação da criança e do jovem" (ALVES, 2001, p. 86).

Frisa-se também a contribuição de Wolfgang Ratke no âmbito das lutas travadas entre as forças feudais e a burguesia, que defendeu a difusão da língua alemã, e, já em 1612 , em meio a intenso conflito, iniciara um projeto educacional para implantar a nova arte de ensinar, começando a elaborar manuais didáticos para o ensino da língua nacional, a partir de 1614.

Portanto, vê-se que as relações entre as produções humanas estão imbricadas com a sociedade em que foram produzidas, como pontua Souza (2010). Conforme indica a autora, a burguesia percebeu que o Latim, no domínio da comunicação social, instituído hegemonicamente e monopolizado pela Igreja Feudal, precisava ser superado para possibilitar melhor fluxo do mercado mundial. É também, nesse sentido que Hoff (2008) indica Ratke como um representante do pensamento burguês que reconhecia a importância de se difundir a língua alemã. Assim como o livro didático emergiu de uma necessidade histórica no interior do desenvolvimento da sociedade capitalista, também a língua nacional ganhou importância quando a burguesia representativa da força histórica no embate com o feudalismo pôs em questão o Latim, no domínio da comunicação.

É importante assinalar que quarenta e cinco anos antes da edição da Didática Magna, conforme Hoff (2008), Ratke, comprometido com o ideário da reforma, combatendo o pensamento instituído no sistema social feudal, inaugurava a instituição escolar e didática, com práticas escolares, na base da divisão do trabalho didático. Porém, há em Ratke a preocupação com o ensino da língua, de modo que sua nova didática representa planos embrionários de uma proposta pautada no uso de manuais didáticos, que ganhou a dimensão de um sistema universal com Coménio. Foi ele, conforme indica Alves em vários de seus escritos, que formulou a pedagogia que expressa a "arte de ensinar tudo a todos" em perfeita harmonia com as necessidades da nova sociedade, criando um instrumento único para todo aprendizado.

Quanto à escola primária - ludus literarius - ou escola pública da língua vernácula ${ }^{\mathrm{vi}}$, ao ensino da arte de ler e escrever, Coménio recomendou banir da escola qualquer autor cujo método não iniciasse o ensino da alfabetização pelas palavras, e usar aquele que instruía pelas coisas úteis e metodicamente, sem fadiga e com grande economia de tempo. Segue-se disso, que nem os manuais didáticos e nem o método eram coisas separadas na proposta de Coménio, e estavam relacionadas às transformações que ocorriam na base material da nova sociedade. Eles eram instrumentos os quais, consoante a um momento histórico caracterizado por mudanças materiais, conferiam unidade às necessidades 
reclamadas à época. Nessa passagem Coménio expressou claramente a acepção de sua proposta no que tange ao ensino das línguas:

As línguas aprendem-se, não como uma parte da instrução ou da
sabedoria, mas como um instrumento para adquirir a instrução e para
comunicar aos outros. Por isso, não devem aprender-se a todas, o que é
impossível, nem muitas, o que é inútil, além de que roubaria o tempo
devido ao estudo das coisas; mas apenas as necessárias. Ora, são
necessárias: a língua materna, para tratar dos negócios domésticos; as
dos países vizinhos, para entrar em relaçóes com eles [...]. Basta
aprender o suficiente para ler e entender os livros. [...] O estudo das
línguas, especialmente na juventude, deve caminhar paralelamente com as
coisas, de modo que se aprenda a entender e a exprimir tanto as coisas
como as palavras. (COMÉNIO, 1957, p. 331, os grifo são nossos).

Vê-se que para ele o ensino da língua consiste em um aprendizado no domínio circunscrito à comunicação. Em sua perspectiva, o conteúdo não é a linguagem como meio para refletir, mas como um instrumento técnico com um fim bem específico. O método reflete o pensamento que considera o aprendizado, no caso aqui o da língua, uma utilidade prática.

Crítico da escola clássica, defendia uma didática para a minimização do esforço do professor, afirmando: "A proa e a popa da nossa Didáctica será investigar e descobrir o método, segundo o qual os professores ensinem menos [...] nas escolas, haja menos barulho, menos enfado, menos trabalho inútil [...] e mais sólido progresso [...]". (COMÉNIO, 1957, p. 44). Aqui, expressa o caráter prático e útil ao desenvolvimento da nova ordem social. Sua abordagem centra-se em torno dos objetos concretos e úteis, haja vista a ênfase nos procedimentos de observação sistemática. Não se devem apresentar às crianças as palavras separadas das coisas, porque isoladas elas não existem e nem desempenham uma função, pois só as coisas dão sentido às palavras. No dizer de Coménio (1957, p. 320) "aprenda-se a fazer fazendo". Para ele a inteligência só pode ser alcançada pela ação se nas oficinas das artes mecânicas os aprendizes não se perdem com especulações teóricas.

Nessa perspectiva, os sentidos são a fonte para todo aprendizado, inclusive o das línguas nas escolas, daí iniciar o ensino a vista das coisas. Então, que os manuais sejam cuidadosamente ilustrados, pois com as imagens das coisas, as crianças devem expressá-las e reproduzi-las, tanto interiormente por meio da memória, como exteriormente por meio das mãos e da língua.

O livro ilustrado de Coménio, Orbis Sensualium Pictus, carrega uma concepção de educação, uma lógica que se expressa na forma de ensinar, uma técnica de instrução que, pela base científica, estabelece concisão e objetividade. Seguindo a sua concepção, é na combinação da imagem com a palavra que se efetiva o aprendizado, pois, se na prática de exercício o ensino da língua for paralelo aos das coisas, permite-se à criança "entender e a exprimir tanto as coisas como as palavras" (COMÉNIO, 1957, p. 332). Conforme Schelbauer (2010), o Orbis Sensualium Pictus concretiza o método universal de Coménius, em resposta às polêmicas de seu tempo. Com a função de subsidiar o ensino do latim às crianças, a partir do empirismo de Bacon, que defende que conhecimento verdadeiro alcança-se pela "observação dos fatos ou trabalho da mente [...]" (Af. I, 1999, p. 33), instituíram-se as bases científicas do ensino.

Enfim, os livros recomendados por Coménio eram livros "práticos", contendo resumo com o conteúdo metodicamente ordenado com o cuidado em expor somente as 
palavras, as frases necessárias, para dominar a técnica da escrita com os elementos sua gramática, omitindo quaisquer elementos "sem importância". Indica-se o conceito utilitarista do ensino da língua escrita, característica que tem se notado na escola, pela ausência da literatura como atividade essencial na alfabetização.

Enfim, já dito anteriormente, a organização do trabalho didático na escola moderna foi forjada no cerne de um movimento de lutas encetado desde Martinho Lutero, encampado por intelectuais e pedagogos como Ratke e Coménio que procuraram superar o modo de pensar e ensinar, instituídos nas escolas feudais. Em outros termos, a escola moderna em sua constituição expressa um momento histórico especifico, adequado à condição material e aos interesses e necessidades de produção da vida social. Nesse sentido, os manuais didáticos produzidos na base das relações sociais de constituição da sociedade burguesa, revelam nos métodos e conteúdos, a lógica pertinente a cada momento histórico desse sistema. Buscou-se, então, na análise do manual Primeiras Lições de Coisas frisar que o método nele impresso respondeu às necessidades históricas, e é isso marcou os limites como instrumento da alfabetização e, com efeito, os limites da própria alfabetização.

2 O MANUAL DE CALKINS - Primeiras Lições de Coisas: o método intuitivo para alfabetizar.

Fins do século XIX, Rui Barbosa de Oliveira (1849-1923) envolveu-se com as reformas educacionais no Brasil, face às aspirações da sociedade capitalista frente ao desenvolvimento tecnológico. O desenvolvimento do país e a modernização pela industrialização conferiam mudanças nas relações de trabalho e, consequentemente, exigiam inovação na educação.

Para fins de seu empreendimento, Rui Barbosa estabelece aspectos fulcrais que envolveria desde a abolição do trabalho escravo, em vista da modernização no modo de produção, a questões de ordem política, constitucional e econômica. Apreendendo as demandas pela base material, as inovações estariam vinculadas à perspectiva de modernização no país. Dessa forma, o estabelecimento de um sistema de ensino público, universal, gratuito e laico tornara-se imprescindível. Nesse contexto histórico, institui-se a necessidade de uma reforma geral na educação e, no âmbito da pedagogia, objetivamente, toma-se como a discussão do método e de instrumentos didáticos para orientar o trabalho do professor.

Rui Barbosa não foi um educador de ofício, como diz Lourenço Filho (1956), mas acompanhando as mudanças que se assentavam na sociedade dos países mais avançados e observando o contexto histórico de transformações sociais que ocorriam no mundo ocidental, o escritor entendia que a educação teria um papel de destaque no fortalecimento da nação. Rui Barbosa, jurista e político burguês, orientando-se por um movimento universal, empenhou-se em romper com as questões internas para a inserção do Brasil no solo dos países industriais. No século XIX, as reformas educacionais, por meio de um ensino de base científica, visaram organizar os sistemas nacionais de ensino. Essa reforma era parte integrante daquele movimento de industrialização, sendo a educação e o trabalho o emblema que preconiza a instituição do método intuitivo e das lições de coisas.

Rui Barbosa, membro e relator da Comissão de Instrução Pública da Câmara dos Deputados, ao analisar os Pareceres sobre a Reforma do Ensino Secundário e Superior (1882) e da Reforma do Ensino Primário e várias Instituições Complementares da Instrução Pública (1883), enviou junto um Projeto substitutivo ao da Reforma do Decreto de abril de 
1879. Nos Pareceres, indicava um programa para a reforma do ensino, no qual dedicava grande parte de suas preocupações ao método e aos livros adotados. Recomendava não só o método intuitivo, como também o livro Primeiras Lições de Coisas, de Calkins, na condição de manual de ensino e único instrumento de mediação do trabalho do professor na escola primária.

Em seus Pareceres, Rui Barbosa indica que a instrução do povo viria a contribuir, especialmente, no âmbito do trabalho. Em seus debates defendeu com determinação a educação para todos, discussão que se desenvolvia em todo o mundo. Uma instrução com os métodos e conteúdos pertinentes, prepararia a criança para a vida, preparando o homem cidadão para exercer, pelo trabalho, a sua função na sociedade. No bojo do sistema burguês, percebia o movimento da sociedade no mundo e a educação era colocada no cerne das discussões entre tantas outras questões. Em fins do século XIX, sua expansão começou a tornar-se uma demanda social.

Acompanhando o movimento cultural, Rui Barbosa creditava o poder incontrastável da ciência para os fundamentos mais gerais de sua pedagogia. Para ele, o pensador original não seria aquele que tinha um só mestre, mas muitos deles, inspirando-se desse modo nos cientistas, filósofos e educadores naturalistas ${ }^{\mathrm{vii}}$, que evidenciavam a ciência burguesa, estabelecendo como princípio de sua metodologia o respeito à natureza e à compreensão evolutiva da criança.

De fato, salientou, sobretudo, a necessidade de uma reforma, desde a administração escolar até a sua organização, envolvendo o trabalho didático, o método e conteúdo, bem como a preparação técnica do professor. Dessa feita, o instrumento que conduziria à prática mais adequada para a racionalização da nova pedagogia era o manual de ensino, Primeiras Lições de Coisas, que se orientava pelo método intuitivo. Por isso a preocupação de Rui Barbosa com a sua tradução ${ }^{\text {viii }}$. Rui Barbosa ao traduzir o manual de Calkins comentou no preâmbulo que, entre os escritos mais notáveis que revelam as obras da experiência e da arte de ensinar, coube ao livro Primeiras Lições de Coisas a mais alta manifestação de prestígio e proeminência. Reconhece, então, que sua indicação desde 1879 para os programas das escolas brasileiras foi decisão acertada. Abordam-se, agora, os contornos da visão de conhecimento, propagada nos princípios que fundamentam o método intuitivo nas Lições de Coisas de Calkins.

\subsection{O manual - Primeiras Lições de Coisas e o método intuitivo}

O imperativo de expansão do ensino sinalizou-se na transição do século XIX para o $\mathrm{XX}$, ocasião em que se assentou intensa discussão em torno dos métodos, dos conteúdos escolares e dos recursos e instrumentos didáticos que responderiam às condições necessárias para organizar o ensino no século XX. Tratava-se, pois, de discutir o método que daria à pedagogia um caráter científico que melhor conviria, em termos objetivos, à prática didática. Foi nesse contexto que o método intuitivo ${ }^{i x}$ de ensino - surgido na Alemanha no século XVIII, divulgado no decorrer do século XIX, nos Estados Unidos e na Europa e conhecido pela expressão lições de coisas - passou a ser matéria de discussão no Brasil, nas primeiras décadas do século XIX e primeira metade do século XX. Esse método foi aclamado como o único adequado à inovação, especialmente para o ensino da instrução primária, ganhando um lugar bem determinado: fazer frente ao chamado ensino tradicional, qualificado como abstrato, livresco, verbalista e inadequado para atender às necessidades da 
formação - mais propriamente de escolarização - que se revelava, naquele momento histórico, com uma perspectiva objetiva, pragmática, funcional e utilitarista.

O livro Primeiras Lições de Coisas, baseado no método intuitivo, tem sua primeira edição datada em 1861, refundida e ampliada em 1870, versão que foi traduzida por Rui Barbosa em 1881 e publicada no Brasil em 1886. A obra em referência é um manual didático, dirigido aos pais e professores primários, que delineia todo o programa a ser desenvolvido na escola elementar, discutindo as bases do ensino e do trabalho didático, no século XIX. Apresenta as lições com os procedimentos metodológicos que os professores devem seguir em sala de aula.

Contando dez anos de publicação, esse livro, em sua quadragésima edição, era composto de seiscentas e três páginas, com vinte e um capítulos. Essa edição, acrescida de novas orientações nas diversas matérias de ensino, inclusive no ensino da leitura, é apresentado por Rui Barbosa como o manual de ensino que contém os verdadeiros princípios e métodos do ensino objetivo. A obra apresenta os princípios fundamentais do método: as lições de base para o trabalho com o número e operações básicas da matemática, o desenho, o escrever e a leitura elementar, o corpo humano e a educação moral. As primeiras orientações são dirigidas aos pais, para a educação dos sentidos no seio da família. Depois, as lições que se reservam ao ensino escolar, com as orientações aos professores. Segundo o princípio das lições de coisas, o processo natural é o fundamento vital desse método; as matérias de ensino, portanto, devem ser graduadas, partindo do mais simples para o mais complexo. Tal como em Pestalozzi, dá-se à criança, "em cada ação, passos gradativos de conhecimentos, em que cada ideia nova é somente um pequeno acréscimo, ao que já é sabido... tudo que a criança precisa aprender deve ser proporcional a sua força [...]" (PESTALOZZI apud EBY, 1970, p. 388).

Ao traduzir as Primeiras Lições de Coisas, Rui Barbosa, já na abertura do livro, apresenta um ofício ${ }^{\mathrm{x}}$, cujo teor se traduz em reivindicações e recomendações com vista à reformulação no ensino primário desde os fins do Império. Os termos da carta colocam em evidência que uma nova ordem de consideração começava a se fazer presente para o ensino público brasileiro. De uma parte, o documento assinalava a intenção de um movimento para ampliá-lo, indicando os limites do ensino individualizado. E de outra parte, a necessidade de pôr em exercício a proposta de um ensino mais prático do que propedêutico; o conteúdo objetivado pelo método em um instrumento como o manual simplificaria o trabalho didático, apresentando lições precisamente sistematizadas. Primeiras Lições de Coisas é um instrumento especializado, com uma função específica: pelo método objetivo, sintetizar, organizar, orientar os conteúdos necessários para a educação que, no século XIX, viria a ampliar-se. Nas palavras de Calkins:

[...] a experiência aprofundou-me e ampliou-me a convicção de que os verdadeiros princípios e methodos da instrução elementar se acham substanciados com a perfeição mais cabal no ensino objectivo; de que não se tem exaggerado a importância deste systema na educação da puerícia; de que sob todas as condições em que póde variar a instrução na escola, os fatos abundantemente confirmam a utilidade prática desse systema. (CALKINS, 1886, p. XXV).

Esse manual, em sua estrutura geral, expõe "o que há de ensinar, como ensinar, quando ensinar" (CALKINS, 1886, p. 56). O texto consiste em dar os fundamentos do método intuitivo e as orientações das matérias, além de um conjunto de anotações complementares sob o nome de Conselhos ao mestre. Ao discutir os problemas do ensino, o que caracteriza a preocupação do autor das Lições de Coisas não são, seguramente, os 
aspectos clássicos do conhecimento, mas o como fazer de acordo com os princípios que informam a intuição. Calkins consagra na sua obra uma sucessão de lições, com as orientações e modelos de como o professor deve proceder. Nela, as atividades sistematicamente graduadas, respeitam os princípios do método intuitivo, que, em síntese, conjuga os conhecimentos pela percepção:

É pelos sentidos que nos advém o conhecimento do mundo material. Os primeiros objetos onde se exercem as nossas faculdades são as coisas e os phenomenos do mundo exterior; [...] É o processo natural de ensinar parte do simples para o complexo; do que se sabe para o que se ignora; dos fatos para as causas; das coisas para os nomes; das ideas para as palavras; dos princípios para as regras [...] (CALKINS, 1886, p. 1-3).

Do ponto de vista epistemológico, fundado no método intuitivo, o ensino deve privilegiar os sentidos de modo que é basilar o mestre lançar mão de uma didática profundamente prática, isto é, tomar a coisa concreta para mediar o ensino, seguir o desenvolvimento natural da infância, e ao professor cabe a excelência na aplicação do método: "[...] a opportunidade própria de cada lição, dispuzemos em passos [...] Em caso nenhum se altere a ordem, na qual se acham graduados os passos de cada assumpto [...]" (CALKINS 1886, p. 56, grifo do autor). Para Calkins o professor que se fizesse perito em desenvolver esse método ensinaria melhor a ler e, também, os assuntos de outra matéria.

Fruto da forma de organização do trabalho didático no método intuitivo, a função do professor se reconfigura numa relação com os instrumentos de trabalho, no molde capitalista. Gradativamente, aquilo que o qualifica como preceptor, na Idade Média, o conhecimento, restringiu-se a habilidades técnicas; sua autonomia, portanto, passou a circunscrever-se à sistematização metódica dos conteúdos previstos nos manuais. O livro Lição de Coisas, pela natureza de seu método, simplifica o trabalho do professor, conforme palavras de Calkins:

Differe o meu livro de outros, elaborados por vários professores, numa feição importante, a saber: exemplifica ao preceptor o modo de haver-se, em cada passo successivo, no desenvolver do espírito das creanças. Depois de dizer o que se há de praticar, passa a mostrar por exemplos demonstrativos o como fazel-o. (CALKINS, 1886, p. XVIII. Grifo do autor).

Pode-se dizer que o livro, na condição de manual, cerceia os conteúdos. Objetivados no manual, os conteúdos devem ser desenvolvidos, passo a passo, consecutivamente, orientado pelo método. Subjaz que, tanto os conteúdos quanto o fazer do professor devam ficar submetidos àquilo que nele está sistematicamente organizado conforme a técnica. Calkins propõe dar aos professores um guia que acondicione o seu fazer. E Rui Barbosa, na condição de tradutor, escreve que Calkins, na elaboração de sua obra, teve a intenção de produzir:

Um livro que correspondesse às necessidades do magistério, oferecendolhe um systema natural, singelo e philosophico de educação primaria, tão claro e circunstanciado, que a todo e qualquer preceptor facultasse não só compreender-lhe os princípios, mas o applical-os, entre os variados incidentes que na execução se the possam deparar. (CALKINS, 1886, p. XIX, grifos nossos). 
Calkins sugere que o seu manual seja para o professor um instrumento tão detalhado, com instruções tão pormenorizadas, que ao professor bastaria incorporar os princípios do método e reproduzir a lição do manual. O professor secundariza-se diante do manual de Calkins, o livro supriria "entre variados incidentes" quaisquer situações de desafio com os quais ele pudesse se deparar. É essa a característica desse instrumento: orientar o trabalho didático objetivamente e evidenciar na técnica a eficiência do professor. O livro didático, instaurado na escola moderna na condição de manual mediador do trabalho docente, contém, a priori, função essencialmente econômica e técnica. Os conteúdos nele objetivados são simplificados, tendo em vista a sua natureza, já que em sua origem foi pensado para superar as questões de ordem social, no campo material e subjetivo.

Por conseguinte, acabam por restringir os conhecimentos mais amplos, justamente, aqueles necessários ao entendimento do que é a sociedade na qual estamos inseridos. De fato, não era essa a razão de ser da escola que se reclamava para a modernidade. As Primeiras Lições de Coisas surgiram em um universo histórico marcado por necessidades materiais, portanto, objetivas. Ao lado das transformações na base material da sociedade, faz-se necessário reformar todo o projeto educativo. Na sociedade moderna do século XIX, estabeleceram-se as concepções de ensino e o método intuitivo traduzia as lições pertinentes e coerentes com os princípios norteadores do utilitarismo que lhes eram peculiares. Dado o pragmatismo que se desenhava na sociedade naquele momento histórico, os livros clássicos refinavam o pensamento, mas não formavam para o ofício, portanto, não eram adequados. Não traduziam as necessidades que despontavam para as condições concretas da vida prática, pois, sem a experiência, ninguém será um profissional-técnico com treino para uma atividade especifica. Coménio (1957, p. 294) já escrevera: “[...] para ensinar as artes e as línguas, como livros fundamentais, devem escolher-se ou fazer-se de novo volumes de pequeno tamanho e de notável utilidade, que exponham as coisas sumariamente [...]".

Logo na apresentação de sua obra, Coménio institui que os fundamentos da arte de ensinar sigam aos das artes mecânicas, indicado por um caminho seguro de pôr as coisas em prática com bons resultados. Eis que as Lições de Coisas são concebidas em todo o seu caráter prático-social. Acrescenta à atividade educativa a engenhosidade que converte a escola em um espaço de intercâmbio com a vida prática. Calkins sublinha o quão judicioso foi Rousseau, ao indicar o esmero que se deve dar aos sentidos das crianças, pois que a exatidão da memória e a precisão do juízo dependiam, na razão direta, da clareza das percepções:

Um menino que vê imperfeitamente, não vingará discorrer com acertos sobre os objetos visíveis, a respeito dos quaes carece de dados sufficientes. Um que não ouve distintamente, não pode julgar exatamente do som; e, se suppuzessemos duplo n'uma crença em relação a outra o sentido do tacto, logo se podia inferir que entre ellas diferia na mesma proporção a perscuidade do juízo (CALKINS, 1886, p. 9).

Todo o ensino pelo método intuitivo valoriza a priori o desenvolvimento de habilidades sensoriais. O treino a tais capacidades perceptivas deveria ser iniciado por meio da observação desde a infância, estendido na adolescência e fortalecido na idade adulta. Do ponto de vista objetivo, o conteúdo do livro é secundário, pelo menos quando se deveriam ensinar a partir dos objetos concretos as coisas práticas da vida, direcionadas a interesses específicos. Conforme Saviani (2010), marcada pela euforia industrialista, na segunda metade do século XIX, a educação aparece como fator de modernidade, ligado à ideia de progresso. Nesse sentido, na difusão da proposta de inovação pelo método intuitivo, todos os objetos se didatizam de modo que vários países, inclusive o Brasil, organizaram 
exposições universais, divulgando a utilização de materiais concretos, já que o método intuitivo tem como fonte as impressões sensoriais.

Nessa perspectiva, o ensino da leitura no método objetivo, antes de ser o de ensinar a ler os livros, deve ser o de ensinar a ler os objetos materiais, suas qualidades, suas propriedades, isto é, as suas funções utilitárias. Infere-se, frente ao exposto, que a leitura se dissociou da literatura quando escrever e ler, a priori, assentou-se no desenvolvimento de habilidades perceptivas. Ler, então, seria identificar a utilidade das coisas para a vida prática. Do ponto de vista objetivo, o conteúdo do livro é secundário, pelo menos quando se deveriam ensinar as coisas à vida prática com eficiência direcionada a interesses específicos, e com economia de tempo.

Segundo o princípio do método: aprender fazendo, parece paradoxal a exclusão do livro nas fases iniciais do ensino da leitura, pois, em tese, começar lendo o livro não seria aprender a ler lendo? Não. Porque naquele método, "aprender fazendo", estava absolutamente enraizado no fazer como treino para desenvolver habilidades técnicas. Não consistia em fazer para aprender, mas em aprender a fazer. Portanto, o aprender não significava desenvolver os conhecimentos como instrumentos para pensar, mas em desenvolver aptidão para fazer as coisas. No item Leitura de livros, apesar de Calkins (1886) mostrar preocupação com o sentido da leitura, e de pretender torná-la atraente e convidativa à criança, o método objetivo, por si mesmo, exclui desse ensino qualquer possibilidade de provocar o desejo de ler. A alfabetização pelo método objetivo, com tantos passos segmentados: "primo, a idea, secundó, os seus symbolos, tertió, arte de representar cada idéa pelos seus signos peculiares [...] (CALKINS, 1886, p, 439), cria, precisamente, uma camisa de força no processo de alfabetização, longe de ser um convite a leitura, é um instrumento para executar o seu estrangulamento.

\section{A ANÁLISE O MÉTODO INTUITIVO NO ENSINO DA LEITURA}

A análise do instrumento eleito para o estudo neste trabalho é tomada sob a perspectiva da proposta comeniana. Como se indicou, anteriormente, explora-se o pressuposto de que os manuais didáticos, como instrumentos de trabalho do professor para mediar a alfabetização, vinculam-se às exigências da especialização instituída no mundo moderno. Infere-se, desse modo, que a proposta de ensino da leitura e da escrita funda-se na base técnica do trabalho imanente à sociedade capitalista burguesa.

Também, já anunciado, sob essa perspectiva a utilização desse instrumento permite a sua problematização em dois aspectos. Primeiro porque, característico de um tipo de organização do trabalho didático, revela o método e o conteúdo pertinente ao seu momento histórico, e, segundo, o processo de alfabetização é conduzido pelas necessidades que o determinam em contexto social específico.

No momento histórico em que se constitui uma nova etapa da sociedade capitalista em fins do século XIX, com demandas singulares, a instituição de um "novo" método seria o caminho adequado para que a prática educacional pudesse cumprir a sua função, em correspondência com a dinâmica da sociedade. Para Rui Barbosa, toda a instrução dependia do estabelecimento de uma lei invariável, que se resolveria pela questão do método. Eis que Primeiras Lições de Coisas, um manual balizado pelo método intuitivo, constitui a racionalidade prática e a objetividade em sintonia com a escola que se deve pôr para o século XIX. 
Presencia-se, assim, o início da concretização daquela forma de ensino preconizada por Coménio, no ensino primário pela objetivação e simplificação do trabalho didático e, por consequência, o início da especialização técnica do professor, evidenciada no manual de ensino. Nas palavras de Calkins (1886, p. XXV) “[...] os verdadeiros princípios do methodos da instrução elementar se acham substanciados com a perfeição mais cabal no ensino intuitivo". Ele se torna a pedagogia para a técnica de ensinar pela intuição sensível, e deve adquirir centralidade nas mãos do professor, o único balizado para orientar o ensino.

As lições mediadas pelos objetos concretos, e obedecendo "as leis fatais de desenvolvimento fisiológico da criança" (RUI BARBOSA, 1883, p. 49), são distribuídas gradualmente no plano de estudo. Numa perspectiva racional, a educação deve articular "mente" e "coração", e a criança tem que ser ativa, conforme os cânones científicos; as lições de coisas, pela observação, substitui o verbalismo formal da "escola antiga". Estabelece-se, por tais princípios, a relação com o trabalho que passa pelos conceitos de "liberdade" e "autonomia", que se circunscreve pela individualidade. Essas qualidades são tanto maiores e possíveis de serem alcançadas na medida do esforço e da inteligência de cada um.

Enfim, as lições de coisas, pelo exercício dos sentidos, educarão a criança nos passos que seu corpo e espírito sejam capazes de atingir. Em outros termos, com suas distintas tendências intelectuais e capacidades individuais, em uma mesma atividade pedagógica, cada um, por suas condições, se desenvolve dentro do princípio da educação integral.

Jules-Gabriel Compayréxi ([191-?]) polemizou as inovações que se colocavam no século XIX, na transição para o século XX. Compayré critica os educadores modernos, pontuando impactos ofensivos ao ensino advindo das novas perspectivas que se anunciavam para o trabalho didático naquele momento. Para ele a tendência dos educadores era a de incorporar as novidades no campo da pedagogia, desprovidos de uma reflexão consequente. A essa irracionalidade indica a aplicação do método intuitivo nas práticas pedagógicas, caracterizando a problemática pela ausência de um estudo aprofundado, que converte a sua utilização de forma equivocada assentando-lhe o exagero.

Para o pedagogo e historiador francês, o que determina o método é a natureza do objeto de ensino. Portanto, não há um método universal para todo o ensino, ambição que se pretende atribuir ao método intuitivo. Compayré nega a intuição como metodologia. Na realidade, ela coexiste no suposto método intuitivo, no qual estão presentes a indução e a dedução. Afirma que a intuição é equivocadamente tomada como método, porque é confundida com lições de coisas. A intuição seria subsídios a um método de ensino, mas não um deles. A lição de coisas por sua vez, seria um método e, como o próprio nome sugere, orientado pela percepção sensível que só se faz mediante objetos. Sua aplicação metodológica nunca deve ser uma lição didática ${ }^{\text {xii }}$, e só se justifica como ponto de partida para o ensino da infância, pois a criança não suporta um discurso por muito tempo. Entretanto, jamais poderá ser método geral para todo o ensino.

Compayré indicou pelo menos três impactos no trabalho educativo quando se instituiu essa inovação para a escola moderna, e que dão origem à secundarizacão de outros elementos que configuram o trabalho didático, intimamente relacionado com o estabelecimento dessa nova perspectiva na relação educativa, cuja pretensão é a de: 1) colocar a criança numa posição ativa; 2) o professor subordinado ao método e 3) os conteúdos construídos na relação com o ambiente, pela percepção sensível.

Distinguir o que está na origem do método intuitivo ou de outro qualquer é fundamental, mas esse conhecimento só ganha significado na medida em que se consiga apreendê-lo organicamente. Porque e como esse método se difunde e o que devemos 
entender por inovação e por processo de difusão, num determinado momento histórico, é a forma nova de racionalizar o antigo, em face de novas necessidades da sociedade. Então, sublinhar o significado e a importância que teria o método intuitivo, impõe uma compreensão dinâmica de sua instituição na educação.

Entretanto, Compayré, sob o influxo dos pensadores iluministas e sob o viés cientificista, com o pensamento fortemente influenciado por René Descartes, desenvolve suas críticas, apresentando uma postura conservadora, a despeito de questões mais amplas que determinam a introdução do método intuitivo na educação naquele quadro de tensão.

De fato, os processos e a forma instituída no método, denominado intuitivo, inauguraram a escola moderna, apresentando a racionalização dos programas escolares, imprimindo a simplificação e objetivação do trabalho didático, na pedagogia moderna. Eis o que diz Buisson (2013, p. 238): "É perfeitamente verdadeiro que, depois do século 18, procuramos e conseguimos simplificar, popularizar o ensino $[\ldots .$.$] ".$

Certamente, pode-se afirmar, que não foi por acaso e nem por uma concepção fragmentária e incongruente, mas, pelo contrário, articulada à base material que se constituiu a expressão da sociedade burguesa. Como afirma Saviani (2009a), a concepção de mundo hegemônica se universaliza pelo seu alto grau de elaboração, obtendo o consenso das diferentes classes que integram a sociedade. Nessa condição se dissemina a pedagogia moderna, que institui uma dada organização do trabalho didático a qual, acolhida sem crítica, se configura como a forma natural de ser do ensino.

A questão é conseguir perceber as transformações inerentes a cada movimento, as formas que as relações assumem e, ainda, a sua dimensão na estrutura social em que elas se encontram. Cabe entender que o método é um instrumento, tal como os conteúdos escolares também o são. Assim, o método que está na origem da ciência moderna e que articula na sua base um pragmatismo necessário, foi um instrumento de luta. Mas, da mesma forma, ele se configura como um instrumento para articular a hegemonia da sociedade capitalista burguesa. Eis o que diz Saviani (2008, p. 32b): "toda postura revolucionária é uma postura essencialmente histórica"; enquanto estiver no processo de transformação radical da sociedade, os interesses coincidem com a perspectiva de mudança; porém, à medida que a classe revolucionária se consolida, os interesses tomam direção contrária àquele que corresponde à transformação e passam a ser conservadores. Assim, no momento em que a burguesia acusa o método tradicional de antifilosófico e desprovido de um caráter científico, constrói os argumentos que defende o novo, na base do método intuitivo.

Note-se que a proposta educacional integrada à ideologia burguesa reflete a ciência fundada entre os séculos XV e XVII, concebendo o método intuitivo como expressão do método científico e, por conseguinte, a metodologia apropriada para substituir todos os outros, na reorganização do modo de ensinar em toda a educação. Vale dizer, com respeito à função histórica dos métodos, que eles constituíram a ciência moderna pela concepção utilitária, daí a sua importância na formação do mundo moderno. Mas, justamente por isso, há que superá-lo.

Da perspectiva que se propôs apreender o objeto de estudo deste trabalho, coloca-se como questão fundamental analisar os limites históricos do método; portanto, importa menos o seu emprego como técnica em si, e mais a sua condição como instrumento de trabalho construído na sociedade moderna. Aos métodos instituídos nessa escola, nomeados como método intuitivo ou Lições de Coisas, devem-se dar um lugar bem expressivo no seio da sociedade que os gerou. Ressalte-se, o livro é todo composto de lições, com atividades orientadas em função dos sentidos, com ênfase no fazer prático, e o professor de primeiras letras deve ser hábil em ensinar "coisas reais". 
A considerar as explicações e os encaminhamentos metodológicos, o método intuitivo é um instrumento com objetivo bem determinado que, didaticamente, se enraíza nas entranhas da modernidade, para especializar o professor na técnica de ensinar pela realidade sensível. Percebe-se pela ordenação sistemática, a perspectiva pragmática que se investe na organização do trabalho didático, que se revela no uso de frases para leitura, tal como abordado no item sobre a leitura de livros: o "conteúdo textual" se reduz à formação de frases que indicam ideias do fazer, de utilidade e de comportamentos. Por exemplo, no sexto passo da lição leitura de livros, o autor indica:

Levae os meninos a dar cópia de que entendem a accepção das palavras, empregando-as mais ou menos deste theor: [...] Vacca. A vacca dá leite. Nadar. Os peixes nadam. Cuidados. Devo ser cuidadoso com os meus livros. Obediente. Sou obediente quando faço o que manda minha mãe. Attento. Procuro ser attento ás minhas lições. (CALKINS, 1886, p. 453).

Naquelas circunstâncias históricas, a leitura se restringe ao estritamente necessário para o seu domínio técnico. $\mathrm{O}$ ensino da língua na escola moderna suprime a leitura do texto na medida em que o raciocínio segmenta o procedimento técnico. Coerente com a lógica que se segue ao advento do capitalismo, a escola prescinde da visão de totalidade. Como diz Souza (2010, p. 13), "desde suas origens a educação, e dentro dela o ensino da leitura, despreza as teorias que reivindicam uma visão de totalidade, optando por 'antiteorias' cada vez mais fragmentadas". (SOUZA, 2010, p. 13). A utilização do manual didático na condição de instrumento mediador do ensino, concentrando-se na leitura objetiva, no quadro preto, na pedra, no mapa, na carta e no livro didático de leitura, conduz na prática, à extinção da leitura enquanto literatura, da leitura de textos literários.

Se se considerar aquele contexto histórico, o objetivo da leitura só podia ser aquele: instrumental. É forjada para informar "os indivíduos, de acordo com as necessidades advindas do trabalho", (SOUZA, 2010, p. 79), nos rudimentos das letras. Formam interpretadores de códigos e privam as crianças de adquirir um pensamento mais elaborado. $\mathrm{O}$ ensino da linguagem pela percepção sensível consiste estritamente para o uso de um sistema de sinais para expressar e comunicar o pensamento na sua forma escrita e falada.

Desse modo, em se tratando da leitura e da escrita, a medida da leitura está na medida em que a criança exercita a identificação dos símbolos como representação das coisas e opere com os caracteres e sons da língua. O manual Primeiras Lições de Coisas traduz o método intuitivo, operando com a percepção sensível, atuando sobre coisas reais, de modo que real só é o objeto empírico. Por esse viés, a linguagem oral traduzida pela linguagem escrita é apreendida puramente como coisa, um signo, um código, um sinal, um símbolo que, na realidade objetiva, nomeia os fatos, os acontecimentos, os eventos, e se caracteriza pela sua utilidade.

As séries de exemplos descritos em Primeiras Lições de Coisas evidencia o aprender a ler e a escrever como resultado da capacidade de aprender as palavras pelo aspecto, pela realidade, pela intuição, pelo cultivo das faculdades de observação. Como bem explica Hoff (2010), a lição de coisas, determinada pela forma intuitiva de apreender as coisas, capta os objetos humanos como se fossem objetos naturais, e não como objetos humanos.

Entrementes, há que se analisar que, por um lado, produziu uma arte de ensinar diferente daquela recebida pelas crianças, nas escolas feudais, por outro, sua postura idealista estabelece uma relação de proeminência do pensamento, de modo que não se distinguem os objetos naturais dos objetos humanizados, como se ambos fossem uma unidade em si mesmos. Uma coisa só pode estabelecer unidade, se vista numa relação una e 
ao mesmo tempo distinta no nível do pensamento. A lição de coisa, orientada pela intuição sensível das coisas, não estabelece essa relação.

A linguagem no rol das obras que o homem produziu, conjuga-se historicamente pelo verbo de seu tempo; em outros termos, a escolha do método para ensinar se estabelece de uma parte, pelas condições materiais e de outra parte, pelos interesses e necessidades peculiares de uma dada sociedade. Assim, o caráter pragmático e técnico na base do método intuitivo foi a matemática para equalizar os problemas da educação básica, na sociedade moderna.

Eis o caráter técnico da alfabetização. A leitura é um instrumento para relacionar, ordenar, classificar, daí associar as coisas e as imagens à palavra, sendo esta, portanto, a via pela qual se configura o papel da linguagem: mais do que interagir com os livros, devese interagir com os objetos. Igualmente, à perspectiva utilitária de Bacon, a orientação de Calkins sintetiza o seu pragmatismo: apenas pelos livros, ninguém seria um perfeito trabalhador, um profissional dotado de habilidades técnicas específicas, pois sem observação e a prática, sem a experiência, ninguém o será.

Para concluir esse texto, frisa-se o que confere sentido a este estudo: apreender as dimensões do pensamento e do fazer humano historicamente. Assim, para ilustrar retomam-se uma passagem da produção de Descartes. Em o Discurso Sobre o Método, o filósofo conta que dedicou muito tempo de sua vida à leitura dos livros, aprendendo muito sobre a cultura de diversos povos, e isso lhe foi salutar.

\begin{abstract}
Mas quando se leva muito tempo viajando, acaba-se por ficar estrangeiro no próprio país; e, quando é muita a curiosidade pelo que se passou nos séculos passados, fica-se, em geral, ignorante do que se faz no presente. Além disso, as fábulas fazem imaginar muitos acontecimentos como possíveis, quando não o são, e mesmo as histórias mais fiéis, quando não modificam ou não aumentam o valor das coisas para torna-las mais dignas para serem lidas pelo menos omitem quase sempre as circunstâncias secundárias ou menos interessantes. Daí resulta que o resto não aparece tal qual é, que os que regulam os seus costumes pelos exemplos que aí se encontram ficam expostos a cair nas extravagâncias dos paladinos dos nossos romances e a conceber projetos que ultrapassem as próprias forças. (DESCARTES, 1991, p. 16).
\end{abstract}

Importa lembrar que essa perspectiva é atributo marcante de um momento histórico em que o método, orientado pela razão e pela experiência, deveria estabelecer as bases para desenvolver uma ciência combativa, para a superação do pensamento articulado pela filosofia escolástica, daí negar a uma dada teoria e conduzir à prática. A despeito dos projetos que envidaram avanços nos feitos da humanidade, há de se considerar que a unilateralidade no pensamento de uma determinada classe social, por consequência, não permite captar a contradição. Por vezes, a despeito da intenção ou do desejo do observador, a realidade humana concreta é uma, mas a perspectiva empírica a enxerga de fora. Gramsci (1978, p. 13) diz que não podemos alcançar a consciência crítica coerente, "sem a consciência da nossa historicidade, da fase de desenvolvimento por ela representada".

$\mathrm{O}$ que se apreendeu nesse estudo é que mudanças se processaram naquele momento histórico e exigiram o restabelecer as ações para a educação correlacionada com o mundo produtivo. No que diz respeito ao ensino da leitura e escrita, o manual Primeiras Lições de Coisas trazia as lições para ensinar a técnica, objetivamente determinada. Nele, não se vê nenhuma discussão sobre algum conteúdo de linguagem ou de escrita para o professor. E, 
também, nenhum indicativo de qualquer tipo de leitura que não fosse ele próprio, nas mãos do professor, e os "livros de leitura". O manual didático, portanto, entra na escola de forma autossuficiente, apresentando-se "como síntese acabada do conhecimento a ser transmitido, [ao que] exclui todas as demais fontes do saber", diz Alves (2001, p, 56).

A instituição das lições de coisas permitiu a ação pedagógica coordenada entre o fazer e perceber, possibilitando a racionalização do trabalho educativo. Constituiu como norma de vida escolar a prática, difundindo-se a ideia de oposição ao abstrato, isto é, a tudo que é inacessível imediatamente aos sentidos. Nesse contexto, a realidade é tomada pelos objetos concretos, entendendo-se concreto tudo que é imediatamente perceptível pela intuição.

Assim, desenhou-se para o aspecto "ativo" uma abstração que desvincula a atividade sensível, como tal, da realidade objetiva. Se se distinguir o empírico de sua base real, não se alcança o concreto, simplesmente porque o sensível descolado do mundo material é uma abstração. Este pequeno trecho marxiano oferece elementos para se pensar a complexidade da relação entre o real e a percepção sensível, por consequência, unilateral na mente humana:

Certa vez, um bravo homem imaginou que se os homens se afogavam era unicamente porque estavam possuídos pela idéia da gravidade. Se retirassem da cabeça tal representação, declarando, por exemplo, que se tratava de uma representação religiosa, supersticiosa, ficariam livres de todo perigo de afogamento. Durante toda sua vida, lutou contra essa ilusão da gravidade, cujas consequências perniciosas todas as características lhe mostravam, através de provas numerosas e repetidas. Esse bravo homem era o protótipo dos novos filósofos revolucionários alemães. (MARX E ENGELS, 1991, p. 18).

Os filósofos destacados por Marx faziam a abstração do real pelo imaginário e nunca estabeleceram a relação entre a realidade concreta e a sensível. Nunca, também, se deram conta da crítica desvirtuada que faziam, porque não a estabeleceram em relação com mundo material.

$\mathrm{Na}$ educação, os defensores do método intuitivo e também críticos da escola antiga, pontuam que o ensino tem sido realizado por métodos abstratos, marcado pela imposição de ideias, fórmulas e conceitos transmitidos dos livros e compêndios mediados pelos mestres. Tais críticos assinalam que esse é um ensino livresco que presta um desserviço para a sociedade moderna, indicando que o livro Primeiras Lições de Coisas, fundado no método intuitivo, se diferencia daqueles, porque liberta as crianças que tanto sofrem com o peso dos conteúdos, transmitidos rigidamente pelos livros e igualmente pelas amarras do mestre. E também os diferencia daquele ensino, pois que ele mesmo se qualifica pelo modo de ensinar, uma vez que permite à criança aprender de maneira natural, intuitivamente. Já foi comentado que o método intuitivo circunscreve o conhecimento ao observado no mundo material, dado pela percepção sensível. Todavia, os próprios instrumentos de trabalho didático, os métodos de ensino e os conteúdos escolares só perdem o caráter abstrato, se examinados no interior de sua prática e produção.

Finalizando, baseado no pressuposto que motivou este estudo, tal como se indicou no início deste tópico, tentou-se chegar aos limites históricos das Lições de Coisas, visto ser ele um manual didático, conveniente a um período em que a especialização se convertia num elemento importante do trabalho didático.

Com as características de seu tempo e, por consequência, dos manuais didáticos para a alfabetização, no sentido de tornar a criança leitora, assim, o livro didático, tal como 
qualquer produção humana, só é concreto se examinado na sua materialidade; portanto, se se restringir a intuição ao conhecimento sensível dado pela percepção do objeto empírico apenas, o método intuitivo é histórico. Apropriar-se desse livro para análise, é uma tentativa de compreender o processo educativo historicamente, e de procurar entender os projetos educacionais, seus avanços e, também, apreender as contradições. Eis aí os subsídios para compreender os problemas da contemporaneidade e abrir caminhos diferentes daqueles, colocando em perspectivas novos projetos.

\section{REFERÊNCIAS}

ALVES, G. L. A produção da escola pública contemporânea. Campo Grande/MS: ed. UFMS: Campinas, SP: Autores Associados, 2001. 288p.

. O Trabalho didático na escola moderna: formas históricas. Campinas, SP: autores Associados, 2005. (Coleção Educação contemporânea).

ARCE, A. A pedagogia na "era das revoluções": uma análise do pensamento de Pestalozzi e Froebel. Campinas, SP: Autores Associados, 2002.

BACON, F. Novum Organum. São Paulo: Editora Nova Cultural Ltda., 1999.

BARBOSA, R. Reforma do ensino primário e várias instituições complementares da instrução pública. Obras Completas de Rui Barbosa, Ministério da Educação e Saúde. Rio de Janeiro, 1946, Vol. X T. II

BUISSON, F. Documento. Conférence sur l'enseignement intuitif par Ferdiand Buisson (31 de agosto de 1878). Trad. Maria Helena Camara Bastos. Hist. Educ. (Online) Porto Alegre, v. 17, n. 39, jan/abr. 2013, p. 231-253.

CALKINS, N. A. Primeiras Lições de Coisas: manual de ensino elementar para uso dos pais e professores. Trad. Rui Barbosa, Rio de Janeiro: Imprensa Nacional, 1886. $613 p$.

COMÉNIO, J. A. A escola da Infância. Trad. Wojciech Andrzej Kulesza. São Paulo: Ed. UNESP, 2011. 120p. (Clássico).

. Didáctica Magna. Trad. e Notas Joaquim Ferreira Gomes. $3^{\text {a }}$ edição.

Fundação Calouste Gulbenkian, 1957.

COMPAYRÉ. J. G. Cours de Pédagogie: théorique et pratique. Vingt-deuxieme édition. Paris. [191-?].

DESCARTES, R. O discurso sobre o método. Trad. Paulo M. de Oliveira. $1^{\text {a }}$ Ed. Bauru, SP: EDIPRO, 1996.

EBY, F. História da Educação moderna: teoria, organização e práticas educacionais (séc. XVI-séc. XX). Trad. Maria Ângela Vinagre de Almeida; Nelly Aleotti, 1970. 
GRAMSCI, A. 1978. Concepção Dialética da História. $3^{\text {a }}$ edição, Rio de Janeiro: Civilização Brasileira, 1978.

HOFF, S. A história da organização do trabalho didático: a palavra e a coisa. In: Brito, S. H. A. de. [et al] (Orgs.) A Organização do Trabalho Didático na História da Educação. Campinas: SP: Autores Associados: HSTEDBR, 2010.

HOFF, S. A história da organização do trabalho didático: a palavra e a coisa. In: Brito, S. H. A. de. [et al] (Orgs.) A Organização do Trabalho Didático na História da Educação. Campinas: SP: Autores Associados: HSTEDBR, 2010.

Lukács, G. A teoria do romance: um ensaio histórico-filosófico sobre as formas da grande épica. São Paulo: Duas Cidades, Ed. 34, 2000. 240p.

LUTERO, M. Obras selecionadas: ética: fundamentos - oração - sexualidade - educação economia, v. 5 2. Ed. Atual. São Leopoldo: Sinodal; Porto Alegre: Concórdia, 2011.

MARX, K. O capital: crítica da economia política. Livro Primeiro. O Processo de Produção do Capital, 12ª edição, Volume I, Bertrand Editora Brasil S.A. 1988.

MARX, K; ENGELS, F. A Ideologia Alemã (Feuerbach). $8^{\text {a }}$ edição. Editora HUCITEC, 1991.

NETTO, J. P. Introdução ao Estudo do Método de Marx. 1. Ed. São Paulo: Expressão Popular, 2011. 64p.

RATKE, W. Escritos sobre A Nova Arte de Ensinar de Wolfgang Ratke (1571-1635): textos escolhidos. Apresentação, tradução e notas Sandino Hoff. Campinas, SP: Autores Associados, 2008.

SAVIANI, D. Educação: do senso comum à consciência filosófica. 18 ed. Campinas, SP: Autores Associados, 2009.

SAVIANI, D. Trabalho didático e história da educação: enfoque histórico-pedagógico. In: Brito, S. H. [et. al] (Org) a organização do trabalho didático na história da educação. Campinas, SP: Autores Associados: HISTEDBR, 2010.

SCHELBAEUR, A. R. Orbis Sensualium Pictus: das lições ilustradas de Comenius no século XVII às lições de coisas da escola primária no século XIX. In: Brito, S. H. [et. al] (Org) a organização do trabalho didático na história da educação. Campinas, SP: Autores Associados: HISTEDBR, 2010. (Coleção Memória Educação).

SOUZA, A. A. A. de. Porque ler os clássicos. In: GOMES, N. S. e ABRÃO, D. (Org.) Pesquisa em Letras: questões de língua e literatura, Curitiba: APPRIS, 2012.

. Manuais didáticos de ensino de língua e literatura na modernidade: gênese e desenvolvimento histórico. Revista HISTEDBR Online, Campinas, número especial, Mai, 2010. p. 6-19. 
TAURO. S. Gabriel Compayré (1843-1913) De la Revista Pedagógica de Milán, eenro 1914.

VYGOTSKY, L.S. Pensamento e Linguagem. $3^{\text {a }}$ edição brasileira, Martins Fontes, 1991.

\author{
i Métodos e Conteúdos de alfabetização em manuais didáticos nos séculos XIX e XX: de Calkins a Lourenço \\ Filho.
}

ii Essa categoria elaborada por Alves (2005) informa a historicidade dos modos de ensinar. Explicita-se aqui, segundo Compayré [191-?], a distinção entre modos de ensinar e métodos propriamente ditos. Os modos de ensinar dizem respeito à forma de organizar o ensino. Eles podem ser: individual, quando o mestre se dirige a apenas um aluno; modo simultâneo, quando o mestre se dirige a vários alunos ao mesmo tempo, a toda uma classe; e modo mútuo, quando o mestre se dirige aos decuriões, que se encarregam de trabalhar com os grupos de alunos sob a sua responsabilidade. Os métodos dizem respeito ao ensino propriamente, que se caracteriza por dois elementos que o regem, a ordem e a forma que articulados devem ser seguidas. (Compayré, [1991-?]) tradução nossa).

iii Esses níveis correspondem em uma sequencia gradual a quatro livros: $O$ Vestíbulo, para a etapa inicial da aquisição da língua, A Porta, corresponde à idade pueril, O Palácio, para a idade juvenil, com trechos de todo gênero de frases, e por fim O Tesoiro, para a fase viril.

iv Doutor em Teologia. Atuou como professor universitário e nessa condição, liderou e apoiou projetos de reforma tanto na Universidade de Wittenberg como em outras universidades. Monge da Ordem de Santo Agostinho, iniciou o movimento de Reforma Religiosa, e como tal, criticou a religião estabelecida: questiona as práticas da Igreja Católica considerando-as indulgentes, abusivas e corruptas. Pôs em questão o próprio fundamento ideológico da ordem social, defendendo o sacerdócio universal a todos os cristãos e o livre acesso às Escrituras. Abordou as implicações educacionais da Reforma, desde 1520, em À Nobreza Cristã , da Nação Alemã, Acerca da Melhoria do Estamento Cristão, onde propôs a reforma das universidades como parte de um programa de reforma geral da sociedade política. Lutero propôs, também, ações para a reforma do ensino nas escolas inferiores, e enfatizou que as Escrituras Sagradas deviam ser o principal objeto de estudo, junto à leitura, à gramática, à dialética e à retórica. Lutero, além de defender a educação para todos, a despeito de gênero e classe social, confere a ela um caráter obrigatório e estatal: "Em minha opinião, porém, também as autoridades têm o dever de obrigar os súditos a mandarem seus fillhos à escola, [...]" (LUTERO, 2011, v. 5, p. 362).

v A manufatura na sua forma clássica, fundada na divisão do trabalho, desenvolveu-se como método de trabalho o sistema de cooperação. Predomina como forma característica do processo de produção capitalista, durante o período propriamente dito que vai de meados do século XVI ao último terço do século XVIII (MARX, 1989, p. 386).

vi Coménio organizou a escola em quatro graus conforme a idade: a escola da infância ou regaço materno, desde a concepção aos 6 anos de idade, a escola primária - ludus literarius - ou escola pública da língua vernácula, dos 6 aos 12 anos de idade, a escola do latim ou do ginásio, dos 12 aos 18 anos de idade e a academia, correspondendo à juventude.

vii Entre esses educadores, citam-se Pestalozzi, Froebel, Coménio, e Rousseau, como influenciadores nos manuais didáticos e nos compêndios de Pedagogia, apontados como os intelectuais ao século XIX, empenhados na renovação e difusão do ensino popular, tendo o método intuitivo como guia, por excelência, para tal empreendimento. Não faremos aqui uma análise de suas proposições, pois a esse respeito já existem contribuições importantes na historiografia educacional, a exemplo da tese de Lancillotti (2008) sobre Pestalozzi e os livros de Arce (2002a, 2002b) sobre Froebel e Pestalozzi. Coménio, por sua vez, foi objeto das reflexões apresentadas no capítulo um deste trabalho.

vii Rui Barbosa informa ainda que, ao traduzir o livro, procurou ser fiel à letra do texto para preservar a sua originalidade. No trato dos sons da linguagem, contudo, era impossível traduzir, uma vez que a linguagem desses dois países - Brasil e Portugal - se compõe de estrutura muito diversa daquela de origem do livro. E no caso do sistema métrico decimal adotado no Brasil, ajusta-se à forma expedida pela Lei de junho de 1872, e em Portugal, pela Lei de 1852, em vigor 
naquele país desde 1862. Rui Barbosa indica, no texto, entre aspas, algumas partes que lhe pertencem, e em notas de rodapé declara "Do tradutor".

viii Rui Barbosa informa ainda que, ao traduzir o livro, procurou ser fiel à letra do texto para preservar a sua originalidade. No trato dos sons da linguagem, contudo, era impossível traduzir, uma vez que a linguagem desses dois países - Brasil e Portugal - se compõe de estrutura muito diversa daquela de origem do livro. E no caso do sistema métrico decimal adotado no Brasil, ajusta-se à forma expedida pela Lei de junho de 1872, e em Portugal, pela Lei de 1852, em vigor naquele país desde 1862. Rui Barbosa indica, no texto, entre aspas, algumas partes que lhe pertencem, e em notas de rodapé declara "Do tradutor".

ix Faz-se no capítulo II da tese, uma caracterização a respeito das raízes do método intuitivo, evidenciando a natureza do caráter científico que lhe é reputado.

${ }^{x}$ O ofício datado de 4 de julho de 1883, foi enviada pela Inspetoria Geral da Instrução Primária e Secundária do Município da Corte ao Ministro e Secretário do Estado de Negócios do Império, Sr. Conselheiro Dr. Francisco Antunes Maciel. (RUI BARBOSA, 1886, p. V.)

xi Jules-Gabriel Compayré (1843-1913), historiador e pedagogo francês, nascido na cidade de Albi na França meridional, capital do departamento de Tarn, em Languedoc. Em dado biográfico, Tauro (1914) informa que Compayré assegurou presença notável entre os teóricos da Pedagogia. A despeito de não se distinguir pela originalidade, foi um eminente historiado da ciência da educação e tenaz colaborador para a difusão da cultura pedagógica, não só na França, como também em outros países, inclusive no Brasil. Autor de numerosas obras, entre as principais cita-se a coleção Os grandes educadores que compõem escritos sobre Rousseau, Pestalozzi, Pécault, Montaigne, Froebel, Fénelon, Herbart e outras grandes expressões na literatura francesa. Essa coleção é representativa das reflexões que estabelece sobre as tendências da inovação escolar no contexto das reformas que se balizam na modernidade. Compayré narra a vida e expõe as doutrinas de homens que exerceram influência na educação moderna, mas estabelece críticas reconhecendo contradições nelas presentes. Em suas análises, destaca-se aqui o seu posicionamento em relação ao método intuitivo. O método intuitivo e as lições de coisas foram expressões por vezes marcadas por ambiguidade e contradições, levantando polêmicas entre os educadores modernos. Nessa discussão, Compayré apresentou uma particularidade, além de questionar a existência de um método intuitivo, debateu aspectos das propostas que se apresentavam ao ensino, e que tenderam a apontar a ênfase da educação no método. Foi nesses termos que considerou a importância desse historiador e pedagogo, dedicando parte do capítulo II da tese à polêmica instituída por Compayré acerca das propostas de inovação a educação moderna.

xii Entendeu-se nessa expressão "lição didática", explicitada por Compayré, aula expositiva sem auxílio de objetos concretos.

Recebido: fevereiro-15 Aprovado: fevereiro-15 